\title{
Deciphering the role of paclitaxel in the SKGT4 human esophageal adenocarcinoma cell line
}

\author{
SEO JU KIM ${ }^{1}$, MYOUNG JA CHUNG ${ }^{2}$, JONG-SUK KIM ${ }^{3}$, BUMSEOK KIM ${ }^{4}$, WOO HYUN PARK ${ }^{1}$, \\ SUHN HEE KIM ${ }^{1}$, SUNG ZOO KIM ${ }^{1}$, JU-SEOG LEE ${ }^{5}$ and SOO MI KIM ${ }^{1}$ \\ Departments of ${ }^{1}$ Physiology, ${ }^{2}$ Pathology and ${ }^{3}$ Biochemistry, Institute for Medical Sciences, Chonbuk National University \\ Medical School, ${ }^{4}$ Laboratory of Pathology, College of Veterinary Medicine, Chonbuk National University, \\ Jeon Ju 561-180, Republic of Korea; ${ }^{5}$ Department of Systems Biology, University of Texas \\ M.D. Anderson Cancer Center, Houston, TX 77054, USA
}

Received May 26, 2011; Accepted July 6, 2011

DOI: 10.3892/ijo.2011.1135

\begin{abstract}
Paclitaxel (taxol) has been used for the treatment of various human tumors and is an exceedingly efficient chemotherapy agent against esophageal cancer. However, the precise molecular mechanisms of paclitaxel effects on human esophageal adenocarcinoma cells are not well understood. MTT assay and cell cycle analysis were performed to examine the mechanism of antiproliferative and cell viability effects of paclitaxel in human esophageal adenocarcinoma cancer cells. Western blotting was also used to examine the cell cycle- and apoptosisrelated proteins. Paclitaxel inhibited the proliferation of SKGT4 cells in a dose- and time-dependent manner with $\mathrm{G}_{2} / \mathrm{M}$ arrest. In addition, paclitaxel induced apoptosis through the activation of caspase-3 followed by PARP degradation. In conclusion, our results suggest that paclitaxel leads to mitotic cell cycle arrest following $\mathrm{G}_{2} / \mathrm{M}$ arrest and induces apoptosis via a caspase-3 pathway in SKGT4 cells.
\end{abstract}

\section{Introduction}

Upper gastrointestinal tumors involving the esophagus are a serious public health problem worldwide. In particular, the west has seen a dramatic increase in the incidence of esophageal adenocarcinoma in the past three decades (1). In the United States alone, it was estimated that approximately 15,000 people died of esophageal adenocarcinoma in $2010(2,3)$ because it often presents at an advanced stage upon which the 5-year survival rate has been reduced to less than $10 \%$ (4-6). Although surgery is the best curative treatment for esophageal adenocarcinoma, chemotherapy is most commonly recommended for patients $(7,8)$. Since paclitaxel is known as an active antitumor agent,

Correspondence to: Dr Soo Mi Kim, Department of Physiology, Chonbuk National University Medical School, 2-20 Keum-AmDong-San, Jeonju 561-180, Republic of Korea

E-mail: soomikim@jbnu.ac.kr

Key words: paclitaxel, $\mathrm{G}_{2} / \mathrm{M}$ arrest, apoptosis, esophageal adenocarcinoma cells it is often used for the treatment of various tumors including melanoma, breast, prostate, and esophageal cancer (9-14). The combination of 5-flurouracil and paclitaxel is currently used against esophageal adenocarcinoma. Clinically, paclitaxel as a single agent has been reported to be an active agent for the treatment of esophageal cancer (15). In fact, apoptotic effects by paclitaxel in human esophageal squamous cell carcinomas cell lines in vitro have been studied with differential sensitivity to paclitaxel $(16,17)$. However, no information is available regarding the effects of paclitaxel on esophageal adenocarcinoma cells in vitro.

Chemotherapeutic agents usually achieve their anticancer effect through $\mathrm{G}_{1} / \mathrm{S}$ or $\mathrm{G}_{2} / \mathrm{M}$ cell cycle arrest. Paclitaxel has also been shown to induce $\mathrm{G}_{2} / \mathrm{M}$ block in various human cancer cells in vitro $(16,17)$. Cell cycle regulators, specifically cyclins, bind to cyclin-dependent kinases (CDKs) and regulate cell cycle progression whereas cyclin-dependent kinase inhibitors (CDKIs) negatively regulate CDKs activities (18-20). Apoptosis (programmed cell death) often occurs in response to chemotherapeutic agents (21). In particular, chemotherapeutic agents have been reported to cause activation of caspases. The activated caspase-3 or -9 play an important role for cell death via activation of poly-(ADP-ribose) polymerase (PARP), a cleaved form of cellular substrates $(22,23)$. Based on these considerations, our present study set out to investigate the cell cycle related antitumor mechanisms of paclitaxel in human esophageal adenocarcinoma cells.

\section{Materials and methods}

Reagents. Paclitaxel was obtained from Sigma-Chemical Co. (St. Louis, MO, USA) dissolved in DMSO at $5 \mathrm{mg} / \mathrm{ml}$ as a stock solution. This dissolved mixture was stored at $-20^{\circ} \mathrm{C}$ until use.

Cell culture. Human esophageal adenocarcinoma cell line, SKGT4, was used in this study and was obtained from Dr Izzo (University of Texas M.D. Anderson Cancer Center). SKGT4 cells were grown in DMEM-F12 medium (Gibco, Grand Islands, NY, USA) supplemented with $10 \%$ heat-inactivated fetal bovine serum (FBS, PAA Laboratories Inc., USA), $100 \mathrm{mg}$ / $\mathrm{ml}$ streptomycin and $100 \mathrm{IU} / \mathrm{ml}$ penicillin (Gibco, Grand Island, 
$\mathrm{NY}$, USA) as a monolayer in $100 \mathrm{~mm}$ dishes (BD, USA) under standard conditions $\left(37^{\circ} \mathrm{C}, 5 \% \mathrm{CO}_{2}\right.$, humidified atmosphere). Each confluent monolayer was washed with phosphate-buffered saline (PBS; Gibco) and detached with $0.05 \%$ trypsin/0.02\% EDTA solution (Gibco) to transfer or passage the cell lines.

Cell growth inhibition assay by MTT. Cell viability of paclitaxel on SKGT4 cells was determined by MTT assay (3-[4,5-dimethylthiazol-2yl]-2,5-diphenyltetrazolium bromide). To the test wells, $100 \mu \mathrm{l}$ of serial diluted paclitaxel was added and $100 \mu \mathrm{l}$ of cell suspension was then plated in 96-well microtitre plates (SPL, Korea) at $1 \times 10^{4}$ cells per well. After exposure to the drug for 1,2 , and 3 days, $50 \mu \mathrm{l}$ of MTT solution $(2 \mathrm{mg} / \mathrm{ml}$ in PBS) was added to each well and the plates were incubated for an additional $3 \mathrm{~h}$ at $37^{\circ} \mathrm{C}$. MTT solution in medium was aspirated off. To achieve solubilization of the formazan crystals in viable cells, $200 \mu 1$ of dimethylsulphoxide (Sigma) was added to each well. The plates were shaken for $30 \mathrm{~min}$ at room temperature and the absorbance was read immediately at a wavelength of $540 \mathrm{~nm}$ with a scanning multiwall spectrophotometer (Spectra MAX 340, Molecular Devices Co., Sunnyvale, CA).

Cell cycle analysis. Cell sample preparation and propidum iodide (PI, Sigma) staining was performed according to the manufacturer's protocol. Briefly, $1 \times 10^{6}$ cells were incubated with or without paclitaxel. Cells were subsequently washed with PBS and incubated with PI (10 $\mu \mathrm{g} / \mathrm{ml})$ containing RNase A at $37^{\circ} \mathrm{C}$ for $30 \mathrm{~min}$. The percentage of cells in the different phases of the cell cycle was measured with a FACstar flow cytometer (Becton-Dickinson), and analyzed using Becton-Dickinson software (Lysis II, Cellfit).

Western blotting. Paclitaxel treated cells and non-treated cells were harvested and suspended in lysis buffer (Intron Biotechno$\operatorname{logy}$, Inc.). After centrifugation for $5 \mathrm{~min}$ at $4^{\circ} \mathrm{C}$ at $13,000 \mathrm{~g}$, the supernatant was collected. The protein concentration was determined using a BCA Protein Assay Kit (Pierce, Rockford, IL, USA). Whole lysate $(20 \mu \mathrm{g})$ was resolved on a $10 \%$ SDS-PAGE gel, transferred onto a PVDF membrane (Bio-Rad, Hercules, CA, USA) by electroblotting and then probed with $\sim 0.1 \mu \mathrm{g} / \mathrm{ml}$ of rabbit anti-human phospho-cdc2, mouse antihuman cyclin A, rabbit anti-human cyclin B1, rabbit anti-human CIP1/WAF1-p21, rabbit anti-human cleaved caspase-3, rabbit anti-human cleaved caspase-9, and rabbit anti-human cleaved PARP antibodies (Cell Signaling Technology, Beverly, MA, USA). The membrane was then washed with TBS-T (10X TBS and $0.1 \%$ Tween-20) and incubated for $1 \mathrm{~h}$ with HRP-linked anti-rabbit and anti-mouse antibodies (Cell Signaling Technology). The blot was developed by using the enhanced chemiluminescence (ECL) kit (Amersham, Arlington Heights, IL, USA).

Statistical analysis. Data are presented as the means \pm SD. Data were analyzed by Student's t-test. P-values $<0.05$ were considered statistically significant.

\section{Results}

Cytotoxic effect of paclitaxel on SKGT4 cells. Cell proliferation assay (MTT) was performed to investigate the effect of paclitaxel

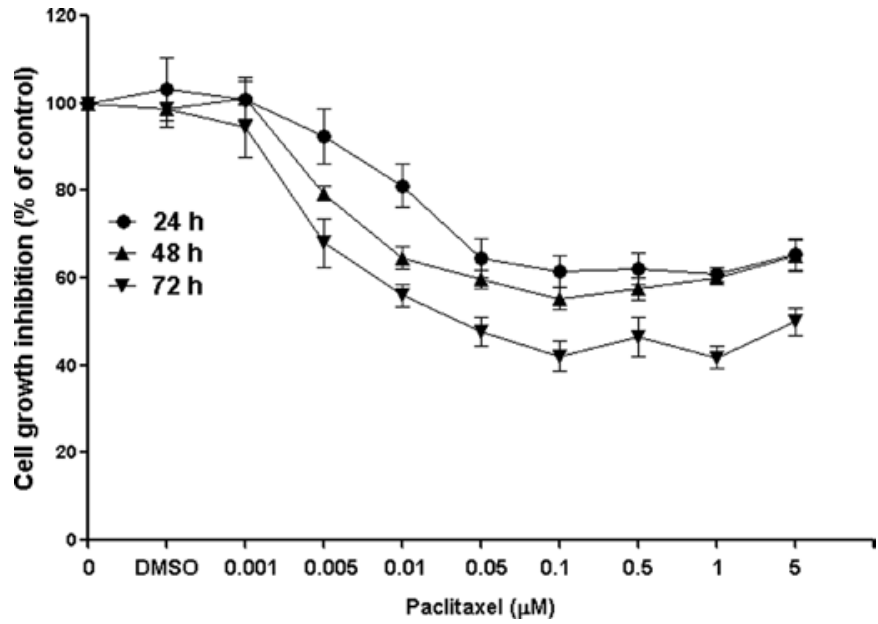

Figure 1. Effect of paclitaxel on growth inhibition of human esophageal cancer cells. Logarithmically growing human esophageal cancer cell line SKGT4 was treated with various concentrations of paclitaxel for 24,48 and $72 \mathrm{~h}$. Cell growth inhibition was assessed by MTT assay. Results are expressed as percentage of control plates containing no paclitaxel. Each point represents the mean $( \pm S D)$ of at least three independent experiments with triplicate dishes.

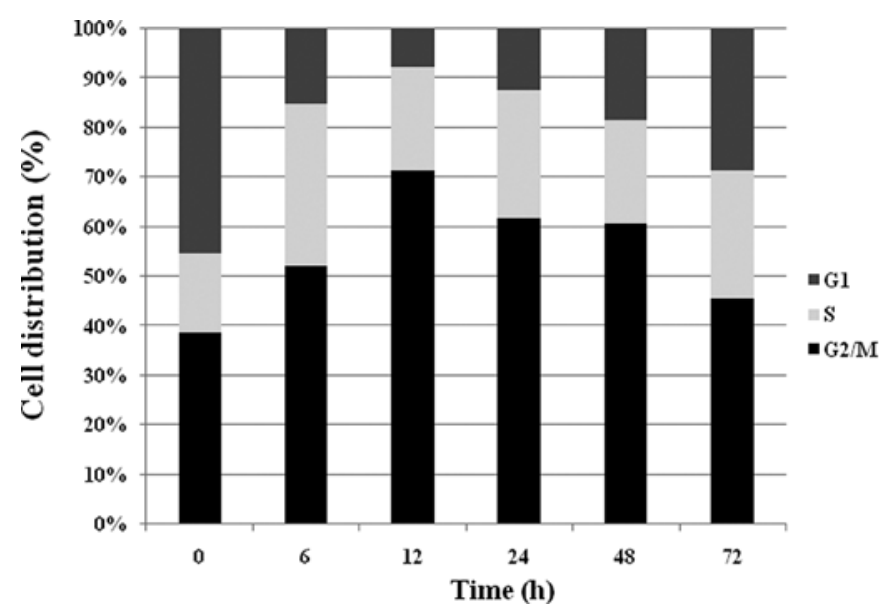

Figure 2. Cell cycle analysis of SKGT4 cells cultured with paclitaxel. Cells were incubated with $50 \mathrm{nM}$ of paclitaxel for different time-points $(0,6,12$, 24, 48 and $72 \mathrm{~h}$ ). Control represents SKGT4 cells which are not exposed to paclitaxel $(0 \mathrm{~h})$. Cell cycle distribution was calculated as the percentage of cells in the $G_{1}, S$ and $G_{2} / M$ phase.

on the SKGT4 cell line. Paclitaxel induced cell growth inhibition in a dose-and time-dependent manner. The $\mathrm{IC}_{50}$ of paclitaxel was $\sim 50 \mathrm{nM}$ (Fig. 1). Based on these data we assumed that paclitaxel has potent antitumor effects, specifically with regards to inhibiting the proliferation of SKGT4 cells in vitro.

Cell cycle regulation by paclitaxel. To elucidate whether paclitaxel causes growth inhibition in the SKGT4 cells, cell cycle distribution was determined by the fluorescence-activated cell sorting (FACS) analysis. The cell cycle fraction was measured at $0,6,12,24,48$, and $72 \mathrm{~h}$ after treatment of $50 \mathrm{nM}$ paclitaxel. As shown in Fig. 2, at $12 \mathrm{~h}$ after treatment, the population of $\mathrm{G}_{2} / \mathrm{M}$ was significantly increased from 34.38 to $54.66 \%(\mathrm{P}=0.05)$. The $\mathrm{G}_{2} / \mathrm{M}$ population reached the highest level at $12 \mathrm{~h}$, and decreased thereafter. At the same time, the percentage of cells in the $\mathrm{S}$ phase was slightly increased from 14.02 to $15.96 \%$. These 


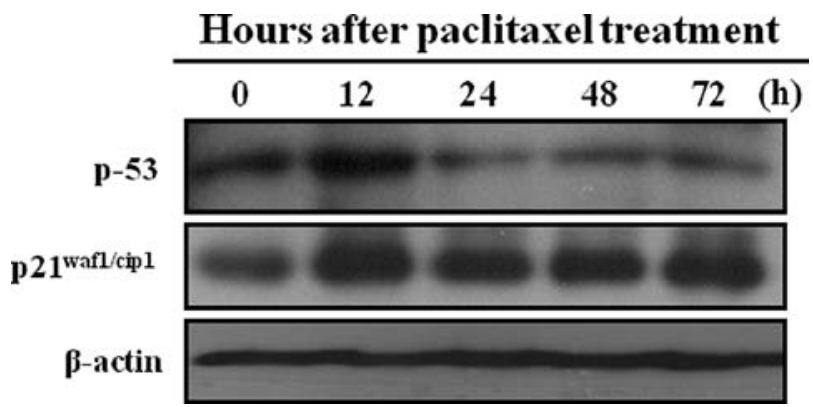

Figure 3. Effect of paclitaxel on p21 ${ }^{\text {wafl/cipl } 1}$ in SKGT4 cells. Cells were harvested at the indicated times after incubation with $50 \mathrm{nM}$ of paclitaxel. Cells were then lysed, and the supernatants were subjected to Western blot analysis. Aliquots of $20 \mu \mathrm{g}$ of protein of extracts were analyzed by $12 \%$ SDS-PAGE, transferred to a PVDF membrane and immunoblotted with the indicated antibodies. $\beta$-actin was used as an internal control.

results indicated that paclitaxel induced $\mathrm{G}_{2} / \mathrm{M}$ phase arrest in SKGT 4 cells by $12 \mathrm{~h}$ after treatment.

Cell cycle regulatory protein expression by paclitaxel. Since paclitaxel induced $\mathrm{G}_{2} / \mathrm{M}$ arrest in the SKGT4 cell line, we next investigated whether there were alterations of cell cycle regulatory proteins such as CDKIs, p21 and p53 after treatment with paclitaxel $(50 \mathrm{nM})$ in SKGT4 cells. The p53 protein levels were drastically increased at $12 \mathrm{~h}$ and gradually decreased from $24 \mathrm{~h}$ (Fig. 3). The $\mathrm{p} 21$ protein expression was also increased by $12 \mathrm{~h}$ after paclitaxel treatment (Fig. 3). Since $\mathrm{G}_{2}$ to $\mathrm{M}$ phase progression is regulated by a number of the $\mathrm{Cdk} /$ cyclin family including cdc2/cyclin B1 complex, we next examined the protein expression levels of phospho-p34 $4^{\text {cdc2 }}$ (Tyr15), p34 ${ }^{\text {cdc2 }}$, cyclin B1, phospho-Wee1 (Ser642), and cyclin A. As shown in Fig. 4, phospho-Wee1 (Ser642) protein expression was increased at $12 \mathrm{~h}$ and then gradually decreased by $72 \mathrm{~h}$ after paclitaxel treatment. Although, the expression of $\mathrm{p} 34^{\mathrm{cdc} 2}$ which is involved in cell cycle arrest in the $\mathrm{G}_{2}$ phase was unchanged after paclitaxel treatment as compared to control, while its phosphorylated form, p34 ${ }^{\mathrm{cdc} 2}$ (Tyr15) was significantly increased at $12 \mathrm{~h}$ and decreased thereafter. Cyclin A protein expression was also increased at $12 \mathrm{~h}$ while no change was observed in the level of cyclin B1 at all time-points after paclitaxel treatment. In addition, the expression of phosphohistone $\mathrm{H} 3$, which induces cell cycle arrest in the $\mathrm{M}$ phase, was significantly increased by $24 \mathrm{~h}$, then gradually decreased (Fig. 4). Therefore, these results suggest that paclitaxel induces the $\mathrm{G}_{2} / \mathrm{M}$ cell cycle arrest in SKGT4 cells.

Induction of apoptosis by paclitaxel in SKGT4 cells. As shown in Fig. 5A, paclitaxel $(50 \mathrm{nM})$ treated SKGT4 cells showed an increased sub- $\mathrm{G}_{1}$ population in a time-dependent manner (control; $1.33 \%$, paclitaxel at $72 \mathrm{~h} ; 20.65 \%$ ). We further investigated apoptosis-related proteins (cleaved-caspase-9, -3 and -PARP) using Western blotting. As seen in Fig. 5B, the expression of the cleaved form of initiator caspase- 9 and -3 gradually increased in a dose-dependent manner at $48 \mathrm{~h}$ after paclitaxel treatment. In addition, a cleaved form of poly-(ADPribose) polymerase (PARP) protein, a major substrate for active caspase- 3 and a hallmark of apoptosis, was observed to gradually increase in a dose-dependent manner (Fig. 5B). This result

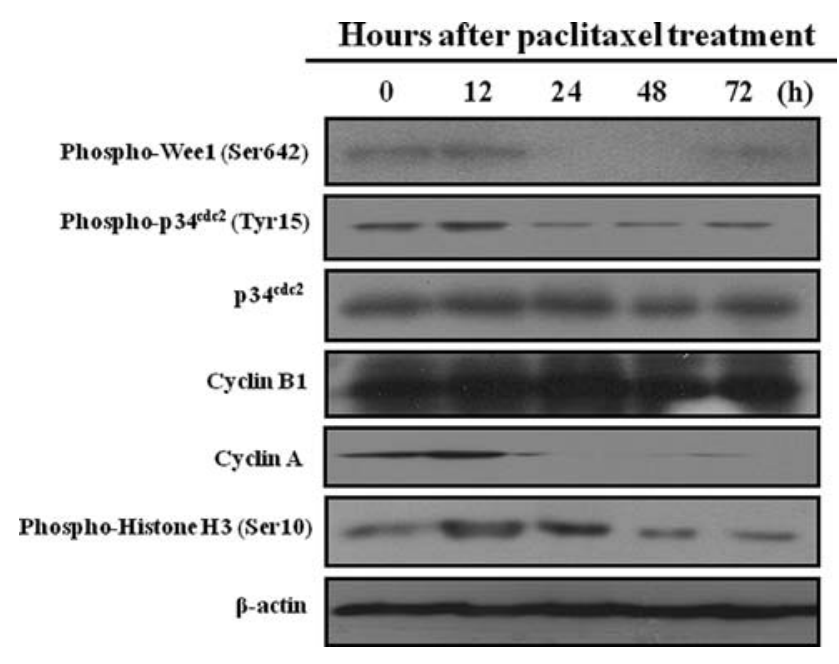

Figure 4. Paclitaxel affected cell cycle-related proteins in SKGT4 cells. Western blot analysis of phospho-Wee1 (Ser642), phosphor-p34 ${ }^{\text {cdc2 }}$ (Tyr15), p34 ${ }^{\text {cdc2 }}$, Cyclin B1, Cyclin A, phosphor-Histone H3 (Ser10) in human SKGT4 cells treated with $50 \mathrm{nM}$ paclitaxel at different time-points $(0,12,24,48$, and $72 \mathrm{~h})$. $\beta$-actin was used as an internal control.

indicated that paclitaxel induced apoptotic cell death in SKGT4 cells.

\section{Discussion}

The purpose of the present study was to investigate the cytotoxic effect of paclitaxel in human esophageal adenocarcinoma cells to elucidate the biochemical mechanism of cell death. The main result of this set of experiments is the observation that paclitaxel leads to $\mathrm{G}_{2} / \mathrm{M}$ cell cycle arrest and induces apoptosis via a caspase-3 pathway in SKGT4 cells.

We used MTT and FACs analysis to ensure paclitaxel induced cell cycle arrest and antiproliferative effect on the human esophageal adenocarcinoma cell line. Paclitaxel induced a time- and dose-dependent inhibition of cellular proliferation of SKGT4 cells. Previously published reports demonstrated similar effects of paclitaxel observed in human esophageal squamous cell carcinoma cells (16). Although, there were different sensitivity effects of paclitaxel on esophageal squamous cell carcinoma cells versus esophageal adenocarcinoma cells, the tendency of paclitaxel to exhibit antiproliferative effects against esophageal cancer appeared to be consistent. In this study, cell cycle analysis revealed that paclitaxel induced the highest $\mathrm{G}_{2} / \mathrm{M}$ growth arrest in SKGT4 cells after exposure to $50 \mathrm{nM}$ of the paclitaxel at $12 \mathrm{~h}$. These observations are in agreement with earlier studies demonstrating paclitaxel induced $\mathrm{G}_{2} / \mathrm{M}$ phase cell cycle arrest in human breast, lung, gastric, and esophageal squamous carcinoma cells $(16,17,24,25)$. Our results suggest that paclitaxel may induce cells to undergo apoptosis as result of the failure of the cell cycle checkpoint function by accumulation of cells in the $\mathrm{G}_{2} / \mathrm{M}$ phase in human esophageal adenocarcinoma cells. We further investigated the cell cycle regulatory molecule after the treatment of paclitaxel to elucidate the precise molecular mechanism of cell cycle regulation. Because p53 is concerned with the regulation of the cell cycle, it is possible that $\mathrm{p} 53$ protein could alter cell sensitivity to paclitaxel treatment. The results showed paclitaxel increased p53 protein expression followed by activation of $\mathrm{p} 21^{\mathrm{WAF}-1 / \mathrm{CPI} 1}$ expression at $12 \mathrm{~h}$. Our findings suggest that 
A
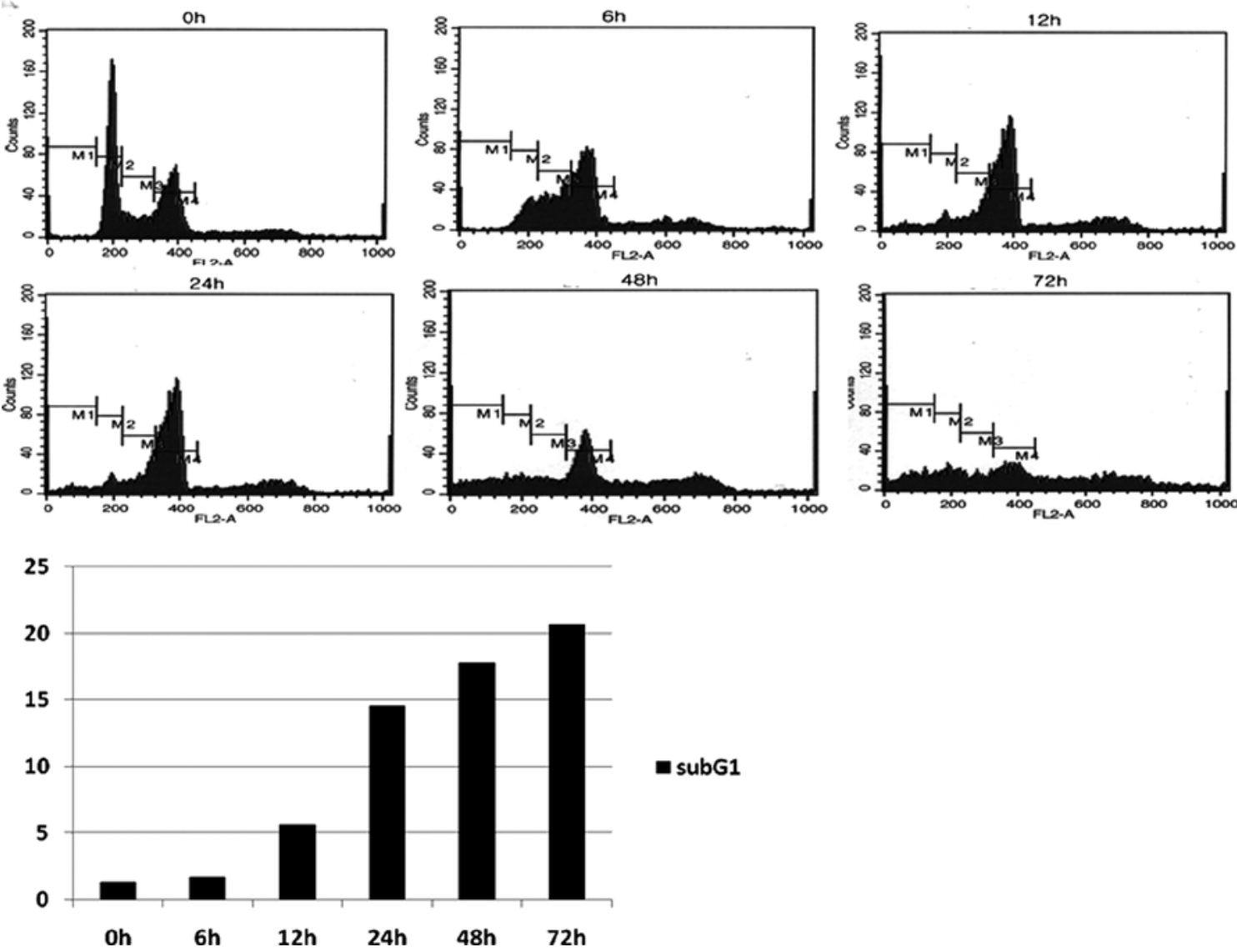

$\mathbf{B}$

\section{$48 \mathrm{~h}$ after paclitaxel treatment}

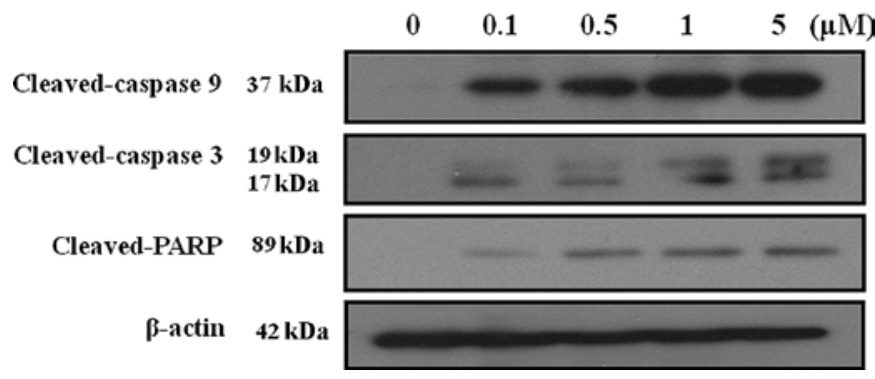

paclitaxel may induce DNA damage and this causes the increase of p53 and p21 protein levels.

In light of the fact that paclitaxel could be related to the $\mathrm{G}_{2} / \mathrm{M}$ checkpoints, we performed Western blot analysis to determine the expression patterns of cell cycle related proteins including phospho-Wee1, phospoho-p34 ${ }^{\mathrm{cdc} 2}, \mathrm{p} 34^{\mathrm{cdc} 2}$, cyclin B1, and cyclin A. It is well known that cdc2/cyclin B1 complex starts to form at the beginning of $\mathrm{S}$ phase and accumulates with cyclin B protein level. It is usually held in an inactive form until $\mathrm{G}_{2}$ phase because of phosphorylation on Thr14 and Tyr15 of cde 2 by the Weel and myt1 protein kinases (26). This helps explain the increased amounts of Tyr15-phosphorylated p34 ${ }^{\text {cdc2 }}$ found to be coupled with $\mathrm{G}_{2}$-arrested cells after DNA damage in several systems (27-29). Our results showed that paclitaxel induced augmentation of Tyr15-phosphorylated p34 ${ }^{\text {cdc2 }}$ expression following and increase in the expression of phospho-Weel for $12 \mathrm{~h}$. However, the expression of cyclin B1 was not affected. Histone $\mathrm{H} 3$ phosphorylation at Ser10 plays an important role in mitotic chromosome condensation $(30,31)$. In the present study,
- subG1

Figure 5. Effect of paclitaxel on sub-G1 population and caspase-mediated apoptosis in SKGT4 cells. (A) Cells were washed with PBS, fixed with $75 \%$ ETOH, washed with PBS again and stained with $10 \mu \mathrm{g} / \mathrm{ml} \mathrm{PI} \mathrm{containing} 10 \mu \mathrm{g} /$ $\mathrm{ml}$ RNase A. The DNA contents of cells $(10,000$ cells/group) were analyzed using FACS analysis (Becton-Dickinson). The percentage of cell populations in sub-G1 phase was calculated from DNA content histograms. (B) Western blot analysis of cleaved-caspase-9, -3, -PARP in SKGT4 cells, which were harvested at $48 \mathrm{~h}$ after treatment with indicated dose points $(0,0.1,0.5,1$ and $5 \mu \mathrm{M})$ of paclitaxel. Equal amounts of cell extracts $(20 \mu \mathrm{g})$ were subjected to SDS-PAGE, transferred to a PVDF membrane, and immunoblotted with the indicated antibodies; Cleaved-caspase- $9,-3$ and -PARP. $\beta$-actin was used as an internal control.

the levels of phospho-histone $\mathrm{H} 3$ was increased from 12 to $24 \mathrm{~h}$ which suggests that paclitaxel may induce cell cycle arrest in the $\mathrm{M}$ phase. Taken together, our results suggest that paclitaxel affects cell cycle arrest through the regulation of multiple regulators in the progression of the $\mathrm{G}_{2} / \mathrm{M}$ phase.

Paclitaxel treatment in SKGT4 cells induced the sub- $\mathrm{G}_{1}$ population at various incubation time-points. Especially, the sub- $\mathrm{G}_{1}$ population was markedly detected after $24 \mathrm{~h}$ treatment, suggesting paclitaxel may induce apoptotic cell death. Since sub-G $\mathrm{G}_{1}$ populations were increased in SKGT4 by paclitaxel, we next measured the levels of apoptosis-related proteins to investigate the molecular mechanism involved in apoptosis by paclitaxel in SKGT4 cells. Apoptosis is a significant feature of cell death that occurs in response to paclitaxel treatment in many cancers. The intrinsic (mitochondrial) and the extrinsic (death receptor) apoptosis induction pathways are well known (16). A cell death signal in the mitochondrial pathway has been implicated to induce the pro-caspase- $9(16,32,33)$. It has been reported that caspase- 9 activates procaspase- 3 as part of the 
apoptotic pathway (34). In this study, it was found that the induction of apoptosis was accompanied by up-regulation of cleaved-caspase-9, and -3. Furthermore, the cleaved form of PARP protein, a major substrate for active caspase- 3 enzymatic protein, was activated in a dose-dependent manner by paclitaxel. Taken together, these results provide strong evidence that the increased cleaved forms of caspase-3, -9 , and -PARP indicated that paclitaxel lead to mitotic cell cycle arrest which might ultimately undergo apoptosis.

In conclusion, paclitaxel markedly inhibits proliferation of esophageal adenocarcinoma cells via $\mathrm{G}_{2} / \mathrm{M}$ phase cell cycle arrest and induces apoptosis via a caspase-3 pathway in SKGT4 cells. Although our findings are consistent with previous studies, further examination of other esophageal adenocarcinoma cell lines is needed.

\section{Acknowledgments}

This work was supported by the research funds of Chonbuk National University in 2010, by the Basic Science Research Program through the National Research Foundation of Korea (NRF) funded by the Ministry of Education, Science and Technology (2009-0064313 and 2011-0014864), and by the Regional Core Research Program/Center for Healthcare Technology Development.

\section{References}

1. Brown LM, Devesa SS and Chow WH: Incidence of adenocarcinoma of the esophagus among white Americans by sex, stage, and age. J Natl Cancer Inst 100: 1184-1187, 2008.

2. Jemal A, Center MM, De Santis C and Ward EM: Global patterns of cancer incidence and mortality rates and trends. Cancer Epidemiol Biomarkers Prev 19: 1893-1907, 2010.

3. Jemal A, Siegel R, Xu J and Ward E: Cancer statistics, 2010. CA Cancer J Clin 60: 277-300, 2010

4. Bollschweiler E, Wolfgarten E, Gutschow $\mathrm{C}$ and Holscher AH: Demographic variations in the rising incidence of esophageal adenocarcinoma in white males. Cancer 92: 549-555, 2001.

5. Mariette C, Balon JM, Piessen G, Fabre S, van Seuningen I and Triboulet JP: Pattern of recurrence following complete resection of esophageal carcinoma and factors predictive of recurrent disease. Cancer 97: 1616-1623, 2003.

6. Kim SM, Park YY, Park ES, et al: Prognostic biomarkers for esophageal adenocarcinoma identified by analysis of tumor transcriptome. PLoS One 5: e15074, 2010.

7. Bosset JF, Gignoux M, Triboulet JP, et al: Chemoradiotherapy followed by surgery compared with surgery alone in squamouscell cancer of the esophagus. N Engl J Med 337: 161-167, 1997.

8. Tepper J, Krasna MJ, Niedzwiecki D, et al: Phase III trial of trimodality therapy with cisplatin, fluorouracil, radiotherapy, and surgery compared with surgery alone for esophageal cancer: CALGB 9781. J Clin Oncol 26: 1086-1092, 2008.

9. Legha SS, Ring S, Papadopoulos N, Raber M and Benjamin RS A phase II trial of taxol in metastatic melanoma. Cancer 65: 2478-2481, 1990

10. Holmes FA, Walters RS, Theriault RL, et al: Phase II trial of taxol, an active drug in the treatment of metastatic breast cancer. J Natl Cancer Inst 83: 1797-1805, 1991.

11. Einzig AI, Wiernik PH, Sasloff J, Runowicz CD and Goldberg GL: Phase II study and long-term follow-up of patients treated with taxol for advanced ovarian adenocarcinoma. J Clin Oncol 10 1748-1753, 1992.
12. Stearns ME and Wang M: Taxol blocks processes essential for prostate tumor cell (PC-3 ML) invasion and metastases. Cancer Res 52: 3776-3781, 1992.

13. Speicher LA, Barone L and Tew KD: Combined antimicrotubule activity of estramustine and taxol in human prostatic carcinoma cell lines. Cancer Res 52: 4433-4440, 1992.

14. Tishler RB, Geard CR, Hall EJ and Schiff PB: Taxol sensitizes human astrocytoma cells to radiation. Cancer Res 52: 3495-3497, 1992.

15. Ajani JA, Ilson DH, Daugherty K, Pazdur R, Lynch PM and Kelsen DP: Activity of taxol in patients with squamous cell carcinoma and adenocarcinoma of the esophagus. J Natl Cancer Inst 86: 1086-1091, 1994.

16. Faried A, Faried LS, Kimura H, et al: Differential sensitivity of paclitaxel-induced apoptosis in human esophageal squamous cell carcinoma cell lines. Cancer Chemother Pharmacol 57: 301-308, 2006.

17. Toiyama Y, Tanaka K, Konishi N, et al: Administration sequencedependent antitumor effects of paclitaxel and 5-fluorouracil in the human gastric cancer cell line MKN45. Cancer Chemother Pharmacol 57: 368-375, 2006.

18. Sherr CJ and Roberts JM: Inhibitors of mammalian G1 cyclindependent kinases. Genes Dev 9: 1149-1163, 1995.

19. Peter M and Herskowitz I: Joining the complex: cyclin-dependent kinase inhibitory proteins and the cell cycle. Cell 79: 181-184, 1994.

20. Elledge SJ and Harper JW: Cdk inhibitors: on the threshold of checkpoints and development. Curr Opin Cell Biol 6: 847-852, 1994.

21. Fisher DE: Apoptosis in cancer therapy: crossing the threshold. Cell 78: 539-542, 1994.

22. Kothakota S, Azuma T, Reinhard C, et al: Caspase-3-generated fragment of gelsolin: effector of morphological change in apoptosis. Science 278: 294-298, 1997.

23. Nunez G, Benedict MA, Hu Y and Inohara N: Caspases: the proteases of the apoptotic pathway. Oncogene 17: 3237-3245, 1998.

24. Liebmann JE, Cook JA, Lipschultz C, Teague D, Fisher J and Mitchell JB: Cytotoxic studies of paclitaxel (Taxol) in human tumour cell lines. Br J Cancer 68: 1104-1109, 1993.

25. Chang YF, Li LL, Wu CW, et al: Paclitaxel-induced apoptosis in human gastric carcinoma cell lines. Cancer 77: 14-18, 1996.

26. Molinari M: Cell cycle checkpoints and their inactivation in human cancer. Cell Prolif 33: 261-274, 2000.

27. Doree $M$ and Galas S: The cyclin-dependent protein kinases and the control of cell division. FASEB J 8: 1114-1121, 1994.

28. Lewin B: Driving the cell cycle: $M$ phase kinase, its partners, and substrates. Cell 61: 743-752, 1990

29. Sleiman RJ, Catchpoole DR and Stewart BW: Drug-induced death of leukaemic cells after G2/M arrest: higher order DNA fragmentation as an indicator of mechanism. Br J Cancer 77: 40-50, 1998.

30. Wei Y, Mizzen CA, Cook RG, Gorovsky MA and Allis CD Phosphorylation of histone $\mathrm{H} 3$ at serine 10 is correlated with chromosome condensation during mitosis and meiosis in Tetrahymena. Proc Natl Acad Sci USA 95: 7480-7484, 1998.

31. Wei Y,Yu L, Bowen J, Gorovsky MA and Allis CD: Phosphorylation of histone $\mathrm{H} 3$ is required for proper chromosome condensation and segregation. Cell 97: 99-109, 1999.

32. Susin SA, Zamzami N and Kroemer G: Mitochondria as regulators of apoptosis: doubt no more. Biochim Biophys Acta 1366: 151-165, 1998.

33. Kroemer G and Reed JC: Mitochondrial control of cell death. Nat Med 6: 513-519, 2000.

34. Barth H, Hoffmann I and Kinzel V: Radiation with $1 \mathrm{~Gy}$ prevents the activation of the mitotic inducers mitosis-promoting factor (MPF) and cdc25-C in HeLa cells. Cancer Res 56: 2268-2272, 1996. 